\title{
Study of Frequency of Prediabetes in Patients with Chronic Hepatitis C Virus Infection
}

\author{
Mostafa Soliman El-Kady ${ }^{1}$, Hatem Samir Abd El-Raouf ${ }^{1}$, \\ Eman Gamal Behiry ${ }^{2}$, Tamer E. Eleraky ${ }^{1}$ and Amr Mohamed Abdel-Ati ${ }^{1}$ \\ ${ }^{I}$ Department of Hepatology, Gastroenterology and Infectious Disease. Faculty of Medicine. \\ Benha University. Egypt. \\ ${ }^{2}$ Department of Clinical and Chemical Pathology .Faculty of Medicine.Benha University. Egypt.
}

Corresponding Author Amr Mohamed AbdelAti

E mail: samerfathi2012@gmai l.com

Key words: hepatitis C virus, Homeostasis Model Assessment of Insulin Resistance, insulin resistance
Background and study aim: Egypt has the highest prevalence of hepatitis $C$ virus (HCV) infection in the world and is facing an epidemic of type 2 diabetes mellitus. The objective of this study was to assess the frequency of prediabetes in patients with chronic HCV infection.

Subjects and Methods: A crosssectional study was performed on 60 HCV patients. Twenty healthy persons were taken as controls. Full history taking, clinical examination, routine laboratory and radiological investigations were done Body mass index (BMI), Waist Hip ratio, serum fasting glucose and fasting insulin were determined. IR was calculated by the Homeostasis Model for
Assessment of Insulin Resistance (HOMA-IR), where values less than 2 has been considered completely normal and higher than 2 as a prediabetic state.

Results: Serum fasting glucose, fasting insulin and HOMA-IR levels were significantly higher among HCV group compared with control group. The frequency of prediabetic (HOMA-IR values >2) among non-diabetic chronic HCV patients is $63.33 \%$.

Conclusion: Chronic HCV patients should be screened regularly for insulin resistance to avoid the double burden of diabetes mellitus and $\mathrm{HCV}$.

in which deficiency or resistance to insulin is the hallmark. Prediabetes mellitus precedes the development of overt type 2 diabetes mellitus (T2DM). It is associated with increased mortality and morbidity, and thus fits well with the criteria of a disease condition [5]. The gold standard for the assessment of IR is the euglycemic hyperinsulinemic clamp technique. Another more practicable and also well-accepted method of measuring systemic IR is the Homeostasis Model Assessment of Insulin Resistance (HOMA-IR). It is calculated by the following formula: fasting glucose $(\mathrm{mmol} / \mathrm{L}) \times$ fasting insulin $(\mu \mathrm{U} / \mathrm{L}) / 22.5$ [6]. In previous reports, HOMA less than 2 has been considered 'completely' normal and higher than 2 as prediabetic state [7]. The progression of prediabetes to T2DM has been examined in a number of populations with varying results. In general, epidemiological studies indicate 
that approximately $25 \%$ of individuals progress to T2DM in 5 years, whereas about $50 \%$ remain prediabetic and about 25\% revert to normal [8]. The aim of this study was to assess the frequency of prediabetes assessed by (HOMA-IR) in patients with chronic HCV infection.

\section{SUBJECTS AND METHODS}

\section{Subjects :}

This study was conducted on 80 subjects attending or admitted to the Department of Hepatology, Gastroenterology and Infectious Diseases and outpatient clinic at Benha University hospital during the period from May 2016 to April 2017 after approval of Benha University ethical committee. They were classified into 3 groups. Group I: included thirty patients with chronic HCV with no evidence of cirrhosis, group II: included thirty patients with $\mathrm{HCV}$ related cirrhosis and group III: twenty apparently healthy volunteers of matched age, sex and BMI were included as control group. Exclusion criteria included clinical evidence of diabetes mellitus, family history of T2DM, non HCV related liver disease, e.g (HBV, alcohol abuse, hepatic schistosomiasis, autoimmune hepatitis, hemochromatosis, Wilson disease, hepatocellular carcinoma, any endocrinal disorder, diabetogenic drugs e.g. (steroids), severe systemic diseases (cardiac, respiratory or renal diseases), obese patients (BMI>30) \& waist hip ratio (for men above 0.9 and for women above 0.85 ).

\section{Materials :}

All the patients and controls were subjected to full history taking, complete clinical examination including (1) BMI: measured as weight in $\mathrm{Kg} /$ height $\mathrm{m}^{2}$ and categorized following World Health Organization classifications. $\mathrm{BMI} \leq 18.5$ : underweight \& BMI of 18.5-24.9: healthy range $\&$ BMI of 25-29.9: overweight \& BMI $\geq 30$ : obese [2]. (2) Waist Hip Ratio (WHR):- measured as waist circumference (measured the circumference of the waist at its smallest points)/ hip circumference (measured the circumference of the hips at their widest point). World Health Organization stated that abdominal obesity is defined as a WHR above 0.9 for males and above 0.85 for females [2].

\section{The following laboratory investigations were done: \\ Sampling:}

Six milliliters of venous blood were withdrawn under aseptic precautions after fasting for $10-12$ hours and distributed as follows: a- 2 milliliters whole blood was put in EDTA vacutainer (violet cap) and mixed up \& down gently which was used to measure CBC.

b- $2 \mathrm{ml}$ on $\mathrm{Na}$ Fluoride serum test tubes, centrifuged at (1500 rpm for 10 minutes). The separated serum is used for the assay of fasting blood sugar.

c- 2 plain test tubes without anticoagulant. The plain test tubes were left till coagulation. After coagulation, samples were centrifuged (at 1500 rpm for 15 minutes). The separated serum was used for the assay of Bilirubin, albumin and Insulin.

\section{Routine Laboratory Investigations:-}

1. CBC was done for all samples using a fully automated cell counter, Mythic 18 (Orphee) from Switzerland.

2. Liver Function Tests: Alanine Transaminase, Aspartate Transaminase applying kinetic method, serum albumin, Prothrombine time and activity, Alkaline phosphatase- Bilirubin (total and direct).

3. Fasting blood sugar applying glucose enzymatic colorimetric method All biochemical tests were done using Biosystem A15 auto-analyzer

\section{Specific Laboratory Investigations :}

1- Fasting insulin level : using ELISA kit supplied from BioTina GmbH. Alter Weg 18, 79112 Freiburg, Germany according to manufacturers' instructions.

2- HOMA- IR (Homeostasis Model Assessment of Insulin Resistance) it was calculated using the equation HOMA-IR = fasting glucose $(\mathrm{mmol} / \mathrm{L}) \quad x$ fasting insulin $(\mu \mathrm{U} / \mathrm{L}) / 22.5$. Cutoff point to define insulin resistance is $\geq 2$.

-- Child-Pugh score: To assess the degree of hepatic decompensation of the patients using biochemical measures (serum bilirubin, INR and serum albumin level) and clinical measures (ascites and hepatic encephalopathy) (Pugh et al., 1973)

\section{Statistical analysis :}

The statistical analysis was conducted using STATA/SE version 11.2 for Windows (STATA corporation, College Station, Texas). The collected data were summarized in terms of mean \pm Standard Deviation (SD) and range for quantitative data and frequency and percentage for qualitative data. Comparisons between the different study groups were carried out using the Chi-square test $\left(\chi^{2}\right)$ and Fisher Exact test (FET) to compare proportions as appropriate. The Student t-test $(\mathrm{t})$ 
was used to detect difference in the mean between two parametric data, while the MannWhitney test (z) was used to compare two nonparametric data. Oneway Analysis Of Variance (ANOVA; F) and the Kruskal Wallis test $\left(\chi^{2}\right)$ were used to compare differences between more than two groups regarding parametric and nonparametric data respectively, followed by posthoc test using the Bonferroni method to detect differences in pairs. The person correlation coefficient (r) and the Spearman Correlation coefficient (rho; $\rho$ ) were used to test for the correlation between estimated parameters as appropriate.

\section{RESULTS}

Table 1 showed that there was no significant difference between the studied groups regarding age, sex, BMI and waist Hip ratio $(\mathrm{P}=1.00,0.43$, $0.46,0.14$, respectively). The mean value of fasting blood glucose was significantly higher in both of group I $(4.9 \pm 0.5)$ and group II $(5 \pm 0.5)$ than controls $(4.7 \pm 0.3) \mathrm{mmol} / \mathrm{L}$ with $\mathrm{P}$ value (0.04). The mean value of fasting insulin level was significantly higher in both of group I

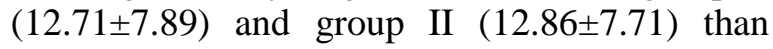
controls $\quad($ mean $=4.12 \pm 1.48)$ with $P$ value $(<0.001)$. The mean value of HOMA-IR was significantly higher in both of group I $(2.94 \pm 1.81)$ and group II $(2.9 \pm 1.81)$ than controls (0.28-1.41) with $\mathrm{P}$ value $(<0.001)$. Table 3 shows that pre diabetes was significantly higher in both group I (63.33\%) and group II (63.33\%) than controls $(0.00 \%) \quad(\mathrm{P}<0.001)$. Child-Pugh score classification of group II showed that 15 patients (50\%) were Child A, 6 patients (20\%) were Child B and 9 patients $(30 \%)$ were Child C. Table 4 showed that there was no significant difference between Child score classification of group II regarding fasting glucose level, fasting insulin and HOMA-IR $(\mathrm{P}=0.5,0.36$ and 0.41 , respectively).

Table (1): Distribution of the studied groups regarding their sex, age, BMI and Waist/Hip ratio

\begin{tabular}{|c|c|c|c|c|c|c|c|c|c|}
\hline \multirow{2}{*}{\multicolumn{2}{|c|}{ Variable }} & \multicolumn{2}{|c|}{$\begin{array}{l}\text { Group I } \\
(\text { no.=30) } \\
\end{array}$} & \multicolumn{2}{|c|}{$\begin{array}{c}\text { Group II } \\
(\text { no.=30) }\end{array}$} & \multicolumn{2}{|c|}{$\begin{array}{c}\text { Group III } \\
(\text { no.=20) }\end{array}$} & \multirow[t]{2}{*}{$\mathbf{X}^{2}$} & \multirow[t]{2}{*}{$\mathbf{P}$} \\
\hline & & No & $\%$ & No & $\%$ & No & $\%$ & & \\
\hline \multirow{2}{*}{ Sex } & Female & 15 & 50.0 & 15 & 50.0 & 10 & 50.0 & \multirow{2}{*}{0.00} & \multirow{2}{*}{1.00} \\
\hline & Male & 15 & 50.0 & 15 & 50.0 & 10 & 50.0 & & \\
\hline $\begin{array}{l}\text { Age } \\
\text { (yrs) }\end{array}$ & $\begin{array}{l}\text { Mean } \\
\pm \mathrm{SD} ; \\
\text { (range) }\end{array}$ & \multicolumn{2}{|c|}{$44.4 \pm 9.11 ;(28-59)$} & \multicolumn{2}{|c|}{$46.57 \pm 8.82 ;(28-59)$} & \multicolumn{2}{|c|}{$43.2 \pm 10.3 ;(24-59)$} & $\begin{array}{c}F= \\
0.86\end{array}$ & 0.43 \\
\hline \multicolumn{2}{|c|}{ BMI $\left(\mathrm{kg} / \mathrm{m}^{2}\right)$} & $25.57 \pm 1.53$ & $23-29$ & $25.92 \pm 1.67$ & $\begin{array}{c}23.5- \\
29.3\end{array}$ & $26.13 \pm 1.71$ & $\begin{array}{c}23.8- \\
29.7\end{array}$ & 0.77 & 0.46 \\
\hline \multicolumn{2}{|c|}{ Waist/Hip ratio } & $0.81 \pm 0.02$ & $\begin{array}{c}0.79- \\
0.89\end{array}$ & $0.82 \pm 0.03$ & $\begin{array}{c}0.79- \\
0.89\end{array}$ & $0.83 \pm 0.03$ & $\begin{array}{c}0.79- \\
0.89\end{array}$ & 2.00 & 0.14 \\
\hline
\end{tabular}

$\mathrm{X}^{2}$ : Chi-square test

F: Oneway Analysis of Variance (ANOVA)

FET: Fisher Exact Test

P: Probability

Table (2): Distribution of the studied groups regarding fasting blood sugar, fasting insulin level and HOMA-IR

\begin{tabular}{|l|c|c|c|c|c|c|c|c|}
\hline \multirow{2}{*}{ Variable } & \multicolumn{2}{|c|}{$\begin{array}{c}\text { Group I } \\
\text { (no.=30) }\end{array}$} & \multicolumn{2}{c|}{$\begin{array}{c}\text { Group II } \\
\text { (no.=30) }\end{array}$} & \multicolumn{2}{c|}{$\begin{array}{c}\text { Group III } \\
(\text { no.=20) }\end{array}$} & \multirow{2}{*}{ F } & \multirow{2}{*}{ P } \\
\cline { 2 - 7 } & Mean \pm SD & Range & Mean \pm SD & Range & Mean \pm SD & Range & & \\
\hline $\begin{array}{l}\text { FBS } \\
(\mathrm{mmol} / \mathrm{L})\end{array}$ & $4.9 \pm 0.5$ & $3.9-6$ & $5 \pm 0.5$ & $3.9-5.9$ & $\dagger+4.7 \pm 0.3$ & $\begin{array}{c}3.9- \\
5.2\end{array}$ & 3.40 & $\begin{array}{c}0.04 \\
(\mathrm{~S})\end{array}$ \\
\hline $\begin{array}{l}\text { Insulin } \\
(\mathrm{IU} / \mathrm{ml})\end{array}$ & $12.71 \pm 7.89$ & $\begin{array}{c}1.4- \\
26.5\end{array}$ & $12.86 \pm 7.71$ & $\begin{array}{c}1.63- \\
26.5\end{array}$ & $\dagger+4.12 \pm 1.48$ & $\begin{array}{c}1.46- \\
6.45\end{array}$ & 12.15 & $\begin{array}{c}<0.001 \\
(\mathrm{HS})\end{array}$ \\
\hline $\begin{array}{l}\text { HOMA- } \\
\text { IR }\end{array}$ & $2.94 \pm 1.81$ & $\begin{array}{c}0.29- \\
5.91\end{array}$ & $2.9 \pm 1.81$ & $0.28-5.9$ & $\dagger+0.85 \pm 0.33$ & $\begin{array}{c}0.28- \\
1.41\end{array}$ & 12.82 & $\begin{array}{c}<0.001 \\
(\mathrm{HS})\end{array}$ \\
\hline
\end{tabular}

F: One way Analysis Of Variance (ANOVA)

$\mathrm{S}$ : Significant $(\mathrm{P}<0.05)$

$\dagger$ : Significant differences compared to Group I $\quad+$ : Significant differences compared to Group II 
Table (3): Frequency of prediabetes among the studied groups

\begin{tabular}{|c|c|c|c|c|c|c|c|c|}
\hline \multirow{2}{*}{$\begin{array}{c}\text { Prediabetes } \\
(\text { HOMA-IR>2) }\end{array}$} & \multicolumn{2}{|c|}{$\begin{array}{l}\text { Group I } \\
(\text { no.=30) }\end{array}$} & \multicolumn{2}{|c|}{$\begin{array}{c}\begin{array}{c}\text { Group II } \\
(\text { no. }=30)\end{array} \\
\end{array}$} & \multicolumn{2}{|c|}{$\begin{array}{c}\text { Group III } \\
(\text { no.=20) }\end{array}$} & \multirow[t]{2}{*}{$X^{2}$} & \multirow[t]{2}{*}{$\mathbf{P}$} \\
\hline & No & $\%$ & No & $\%$ & No & $\%$ & & \\
\hline Yes & 19 & 63.33 & 19 & 63.33 & 0 & 0.0 & \multirow{2}{*}{24.13} & \multirow{2}{*}{$<0.001(\mathrm{HS})$} \\
\hline $\mathrm{No}$ & 11 & 36.67 & 11 & 36.67 & 20 & 100 & & \\
\hline
\end{tabular}

$\mathrm{X}^{2}$ : Chi-square test

Table (4): Correlation between Child score \& FBS, fasting insulin and HOMA-IR in group II

\begin{tabular}{|l|c|c|c|c|c|c|c|c|}
\hline \multirow{2}{*}{ variable } & \multicolumn{2}{|c|}{$\begin{array}{c}\text { Child A } \\
\text { (no.=15) }\end{array}$} & \multicolumn{2}{c|}{$\begin{array}{c}\text { Child B } \\
\text { (no.=6) }\end{array}$} & \multicolumn{2}{c|}{$\begin{array}{c}\text { Child C } \\
\text { (no.=9) }\end{array}$} & \multirow{2}{*}{ F } & \multirow{2}{*}{ P } \\
\cline { 2 - 7 } & Mean \pm SD & Range & Mean \pm SD & Range & Mean \pm SD & Range & & \\
\hline FBS (mg/dl) & $92.53 \pm 9.64$ & $71-105$ & $89.5 \pm 11.64$ & $\begin{array}{c}77- \\
106\end{array}$ & $87.89 \pm 7.97$ & $75-99$ & 0.70 & 0.5 \\
\hline $\begin{array}{l}\text { Insulin } \\
\text { (IU/ml) }\end{array}$ & $11.77 \pm 7.52$ & $2-23$ & $10.97 \pm 7.3$ & $3.1-21$ & $15.95 \pm 8.21$ & $\begin{array}{c}1.63- \\
26.5\end{array}$ & 1.06 & 0.36 \\
\hline HOMA-IR & $2.71 \pm 1.84$ & $0.4-5.9$ & $2.37 \pm 1.58$ & $\begin{array}{c}0.68- \\
4.24\end{array}$ & $3.56 \pm 1.9$ & $\begin{array}{c}0.28- \\
5.88\end{array}$ & 0.92 & 0.41 \\
\hline
\end{tabular}

F: One way Analysis Of Variance (ANOVA)

\section{DISCUSSION}

Hepatitis $\mathrm{C}$ virus (HCV) infection is one the main causes of chronic liver disease worldwide. The number of chronically infected persons worldwide is estimated to be about 160 million, but most are unaware of their infection [1]. Since HCV has been discovered in late 1980, chronic hepatitis C (CHC) has become a complex multifaceted disease with several extra hepatic manifestations [9].

Numbers of studies have demonstrated a strong association between $\mathrm{HCV}$ infection and insulin resistance (IR), providing possible link between this infection and diabetes mellitus [4]. IR is strongly connected with chronic hepatitis $\mathrm{C}$ (CHC) and IR can be developed early in the course of CHC [10]. Type II diabetes mellitus (T2DM) is more common in patients with chronic HCV than in the overall public and chronic hepatitis B patients [11]. IR has a major role in development of T2DM and it is the best predictor for the development of T2DM, and it assumes an essential part in development of T2DM [12]. HCV advances the progression of IR directly by affecting insulin signaling pathway at the cellular level. In addition, IR may play a role in the progression of the liver disease. In euglycemic individuals the estimation of HOMA-IR level helps to quantify IR [13]. Diabetes can adversely affect the course of CHC [14]. In this study we aimed to assess the frequency of prediabetes assessed by (HOMAIR) in patients with chronic HCV infection.

In this study, statistical analysis revealed significant difference between the studied groups as regard fasting blood glucose; it was higher in both of group I and group II than controls, and there was no significant difference between group I and group II. In addition, in this study statistical analysis revealed significant difference between the studied groups as regard fasting insulin level; it was higher in both of group I and group II than controls and there was no significant difference between group I and group II. In addition, statistical analysis revealed significant difference between the studied groups as regard HOMA-IR; it was higher in both of group I and group II than controls and there was no statistically significant difference between group I and group II. This was in agreement with Desouky et al. [15] \& Ali et al. [16] \& Souza et al. [17] and Jason et al. [18] who had demonstrated a strong association between HCV and IR and proved that IR has a high prevalence among patients of chronic $\mathrm{HCV}$ and found that HCV patients had significantly higher levels of all markers of IR, including fasting glucose, fasting insulin and HOMA-IR.

In this study, $63.33 \%$ of group I were prediabetics (HOMA-IR>2) and also $63.33 \%$ of group II were prediabetics while none of the control group was prediabetic, so the frequency of prediabetes 
among non-diabetic chronic HCV patients was $63.33 \%$. This high prevalence is consistent with Desouky et al. [15] \& Ali et al. [16] and DelgadoBerrego et al. [19] who found that the prevalence of prediabetes among $\mathrm{HCV}$ patients was $(63.8 \%$, $64 \%$ and $62 \%$ respectively), however it was higher than a previous Pakistani study where $51 \%$ of their chronic HCV patients had IR [20].

IR occurs in $\mathrm{HCV}$ patients through different mechanisms. One of these mechanisms is interfering with insulin signaling pathway in hepatocytes and increasing the inflammatory response with production of cytokines such as TNF-a and interleukin 6 and increasing oxidative stress [21].

$\mathrm{HCV}$ infection also promotes the expression of glucose 6 phosphatase (G6P) and phosphorenolpyruvate carboxykinase 2 (PCK2) leading to increased glucose production and enhancement of IR [22]. Another mechanism which is triggered by HCV is down regulation of the expression of glucose transporter 4 (GLUT4), which is necessary for the uptake of glucose. Thus, glucose uptake is decreased leading to an increase in plasma glucose and the development of IR. Another explanation of IR could be the expression of HCV core protein, which initiates IR through alterations in signaling in the insulin receptor substrate-1 pathway [23].

This study also showed that there was no significant difference between Child score classification of group II regarding fasting glucose level, fasting insulin and HOMA-IR and this ensured that in this study IR was not connected with the severity of liver disease. This is consistent with Ali et al. [16] \& Mohamed et al. [24] and Li-fen et al. [25] and Hui et al. [26] who demonstrated that prediabetes in $\mathrm{HCV}$ is not connected with the severity of liver disease, and no correlation between liver fibrosis and HOMAIR values and IR is a direct vial feature. It agreed also with Lecube et al. [27] who studied groups of patients with $\mathrm{CHC}$ and chronic hepatitis B matched by age, sex, BMI and fibrosis stage, HOMA index was found higher in hepatitis $\mathrm{C}$ patients.

On the other hand these results disagreed with Jason et al. [18] who assessed the extent of IR in relation to the severity of liver disease and hepatic fibrosis and found that, increased HOMA-IR values was associated with a higher rate of fibrosis progression and more advanced stages of hepatic fibrosis. Also theses results disagreed with Furutani et al. [28] who concluded that IR was connected with impaired glucose tolerance and the severity of the liver disease in non-diabetic patients with HCV infection.

\section{CONCLUSION}

This study showed that the frequency of prediabetes among non-diabetic chronic HCV patients was $63.33 \%$. In addition, prediabetes in chronic HCV patients was not connected with the severity of liver disease and insulin resistance is a direct viral feature. Also this study concluded that HCV patients should be assessed for IR and prediabetes in their routine evaluation, to avoid the double burden of DM and HCV.

Funding: None.

Conflicts of interest: None.

Ethical approval:Approved .

\section{REFERENCES}

1- European Association for the study of the liver. EASL Recommendations on treatment of Hepatitis C. J Hepatol 2015; 63 (1): 199-236.

2- World Health Organization. Guidelines for the screening, care and treatment of persons with chronic hepatitis $\mathrm{C}$ infection. WHO web site. 2016.

3- Kandeel A, Genedy M, El-Refai S, Funk AL, Fontanet A, Talaat M. The prevalence of hepatitis C virus infection in Egypt 2015: implication for further policy on prevention and treatment. Liver Int 2017; 37(1):45-53.

4- Narita R, Abe S, Kihara Y, Akiyama T, Tabaru A, Otsuki M. Insulin resistance and insulin secretion in chronic hepatitis $\mathrm{C}$ virus infection. $J$ Hepatol 2004; 41:132-138.

5- Eldin WS, Emara M, Shoker A. Prediabetes: a must to recognise disease state. Int J Clin Pract 2008; 62:642-648.

6- Hoehn KL, Salmon AB, Hohnen-Behrens C, Turner N, Hoy AJ, Maghzal GJ et al. Insulin resistance is a cellular antioxidant defense mechanism. Proceedings of the National Academy of Sciences of the United States of America 2009; 106(42):17787-17792.

7- Romero-Gómez M, Del Mar Viloria M, Andrade RJ, Salmerón J, Diago M, Fernández-Rodríguez $\mathrm{CM}$ et al. Insulin resistance impairs sustained response rate to peginterferon plus ribavirin in chronic hepatitis C patients. Gastroentrology $2005 ; 128: 636-641$.

8- Larson H, Lindgarde F, Berglund G, Ahren B. Prediction of diabetes using ADA or WHO criteria in post-menopausal women: a 10-year follow up study. Diabetologia 2004; 43: 12241228.

9- Zekry A, McHutchison JG, Diehl AM. Insulin resistance and steatosis in HCV infection. Gut 2005; 54:903-906. 
10- Puri P, Sanyal AJ. Role of obesity, insulin resistance and steatosis in hepatitis $\mathrm{C}$ virus infection. Clin Liver 2006; 10 :793-819.

11- Lecube A, Hernandez C, Genesca J, Esteban JI, Jardi R, Simo R. High prevalence of glucose abnormalities in patients with hepatitis $\mathrm{C}$ virus infection: a multivariate analysis considering the liver injury. Diabetes Care 2004; 27: 1171-1175.

12- Lillioja S, Mott DM, Howard BV, Bennett PH, Yki-Jarvinen H, Freymond D. Impaired glucose tolerance as a disorder of insulin action: longitudinal and cross-sectional studies in Pima Indians. N Engl J Med 1988; 318: 1217-1225.

13- Fartoux L, Poujol-Robert A, Guechot J, Wendum $\mathrm{D}$, Poupon R, Serfaty L. Insulin resistance is a cause of steatosis and fibrosis progression in chronic hepatitis C. Gut 2005; 54: 1003-1008.

14- Cimino L, Oriani G, D'Arienzo A, Manguso F, Loguercio $\mathrm{C}$, Ascione A et al. Interactions between metabolic disorders (diabetes, gallstones and dyslipidemia) and the progression of chronic hepatitis $\mathrm{C}$ virus infection to cirrhosis and hepatoceullar carcinoma. A cross-sectional multicenter survey. Digest Liver Dis 2001; 33: 240-246.

15- Desouky DE, Kasemy Z, Abdel-Hamid AE, Omar MS. Insulin resistance and prediabetes in hepatitis C virus patients. Am J Med Sci 2015; 350:77-80.

16- Ali AA, El-Deeb GS, Essa AS and Ahmed NS. Study of frequency of prediabetesin Egyptian patients with chronic hepatitis $\mathrm{C}$ virus infection. Menoufia Med J 2014; 27:453-457.

17- Souza AF, Pace FH, Chebli JM, Ferreira LE. Insulin resistance in non-diabetic patients with chronic hepatitis $\mathrm{C}$ what does it mean? Arq Bras Endocrinol Metabol 2011; 55: 412-4418.

18- Jason M.R, Archana SUD, Geoffrey C, Faree I, Priyanka B. Insulin resistance is associated with chronic HCV and virus infection fibrosis progression. Gastroenterology 2003; 125: 1659 1704.
19- Delagado-Borrego A, Casson D, Schoenfeld D, Somsouk M. HCV is independently associated with increased insulin resistance after liver transplantation. Transplantation 2004; 77:703710.

20- Kiran Z, Zuberi BF, Anis D, Qadeer R, Hassan $\mathrm{K}$, Afsar $\mathrm{S}$. Insulin resistance in non-diabetic patients of chronic Hepatitis C. Pakistan Journal of Medical Sciences 2013; 29:201-204.

21- Hung CH, Lee CM, Lu SN. Hepatitis C virus associated insulin resistance: pathogenic mechanisms and clinical implications. Expert Rev Anti Infect Ther 2011; 9:525-533.

22- Bose SK, Shrivastava S, Meyer K, Ray RB, Ray R. Hepatitis C virus activates the mTOR/S6K1 signaling pathway in inhibiting IRS-1 function for insulin resistance. J Virol 2012; 86:63156322.

23- Wilson C. Hepatitis C infection and type 2 diabetes in American-Indian women. Diabetes Care 2004; 27: 2116-2119.

24- Mohamed AA, Loutfy SA, Craik JD, Hashem AG, Siam I. Chronic hepatitis c genotype-4 infection: role of insulin resistance in hepatocellular carcinoma. Virol J 2011; 8:496.

25- Li-fen W, Chi-hong WU, Yuan S, Xiao F, Huo $\mathrm{Na}$. Prevalence of abnormal glycometabolism in patients with chronic hepatitis $\mathrm{C}$ and related risk factors in China 2011. Chinese Medical Journal; 124 (2):183-188.

26- Hui JM, Sud A, Farrell GC, Bandara P, Byth K, Kench JC. Insulin resistance is associated with chronic hepatitis $\mathrm{C}$ virus infection and fibrosis progression. Gastroenterology 2003; 125:16951704.

27- Lecube A, Hernandez C, Genesca J, Simo R. Proinflammatory cutokines, insulin resistance and insulin secretion in chronic hepatitis $\mathrm{C}$ patients 2006. Diabetes Care; 29:1096-1101.

28- Furutani M, Nakashima T, Sumida Y, Hirohama A, Yoh T, Kakisaka $\mathrm{Y}$ et al. Insulin resistance/beta-cell function and serum ferritin level in non-diabetic patients with hepatitis $\mathrm{C}$ virus infection. Liver Int 2003; 23:294-299. 